\title{
Terrestrial Gastropoda from the caves of Presidente Olegário, southeastern Brazil
}

\author{
Rodrigo B. Salvador ${ }^{1 *}$, Fernanda S. Silva ${ }^{2}$, Daniel C. Cavallari ${ }^{3 ®}$ \& Luiz Ricardo L. Simone R $^{(\mathbb{D}}$ \\ ${ }^{1}$ Museum of New Zealand Te Papa Tongarewa. Wellington, New Zealand. \\ ${ }^{2}$ Universidade de São Paulo, Museu de Zoologia, São Paulo, SP, Brasil. \\ ${ }^{3}$ Universidade de São Paulo, Faculdade de Filosofia, Ciências e Letras de Ribeirão Preto, \\ Ribeirão Preto, SP, Brasil. \\ *Corresponding author: salvador.rodrigo.b@gmail.com
}

SALVADOR, R.B., SILVA, F.S., CAVALLARI, D.C., SIMONE, L.R.L. Terrestrial Gastropoda from the caves of Presidente Olegário, southeastern Brazil. Biota Neotropica 21(2): e20201169. https://doi.org/10.1590/1676-0611-BN-2020-1169.

\begin{abstract}
Samples of terrestrial gastropods were collected year-round in seven caves in Presidente Olegário municipality, Minas Gerais state, southeastern Brazil, during several expeditions from 2012 to 2014. Twenty-four taxa (plus a single freshwater species), mainly stylommatophorans, were found in the material. The following species are reported for the first time for Minas Gerais state: Alcadia iheringi Wagner, 1910 and Helicina sordida King, 1831 (Helicinidae); Cecilioides consobrina (d'Orbigny, 1841) (Ferussaciidae); Entodina gionensis Morretes, 1940 and Scolodonta interrupta (Suter, 1900) (Scolodontidae); Megalobulimus sanctipauli (Ihering \& Pilsbry, 1900) (Strophocheilidae); Drymaeus coarctatus (Pfeiffer, 1845) (Bulimulidae); Habroconus semenlini (Moricand, 1846) (Euconulidae); and Solaropsis aff. rosaria (Pfeiffer, 1849) (Solaropsidae). Furthermore, the species Drymaeus iracema (Simone, 2015) and Drymaeus terreus (Simone, 2015) are synonymized with Drymaeus coarctatus (L. Pfeiffer, 1845).

Keywords: Minas Gerais; Neritimorpha; Stylommatophora; stygofauna; troglofauna. .
\end{abstract}

\section{Gastrópodes terrestres de cavernas da região de Presidente Olegário no sudeste brasileiro}

Resumo: Amostras de gastrópodes terrestres foram coletadas em sete cavernas na região do município de Presidente Olegário, Minas Gerais, Brasil, durane múltiplas expedições ao longo dos anos de 2012 a 2014. Vinte-e-quatro táxons (mais uma única espécie dulciaquícola) foram encontrados, em sua maioria Stylommatophora. As seguintes espécies são aqui reportadas pela primeira vez para o estado de Minas Gerais: Alcadia iheringi Wagner, 1910 e Helicina sordida King, 1831 (Helicinidae); Cecilioides consobrina (d'Orbigny, 1841) (Ferussaciidae); Entodina gionensis Morretes, 1940 e Scolodonta interrupta (Suter, 1900) (Scolodontidae); Megalobulimus sanctipauli (Ihering \& Pilsbry, 1900) (Strophocheilidae); Drymaeus coarctatus (Pfeiffer, 1845) (Bulimulidae); Habroconus semenlini (Moricand, 1846) (Euconulidae); e Solaropsis aff. rosaria (Pfeiffer, 1849) (Solaropsidae). Além disso, as espécies Drymaeus iracema (Simone, 2015) e Drymaeus terreus (Simone, 2015) são aqui sinonimizadas com Drymaeus coarctatus (L. Pfeiffer, 1845).

Palavras-chave: Minas Gerais; Neritimorpha; Stylommatophora; estigofauna; troglofauna. 


\section{Introduction}

Brazilian cave-dwelling invertebrates have historically received scarce attention from researchers (Simone \& Moracchioli 1994; Bichuette \& Trajano 1999, 2003; Trajano \& Bichuette 2010), a fact that is even more marked for mollusks (Salvador, 2019b). During the past decade, however, Dr. Maria E. Bichuette and her team from the Universidade Federal de São Carlos (UFSCar; São Carlos, Brazil) have been conducting collecting expeditions to cave systems throughout Brazil focusing on several animal taxa. The molluscan material they collected has been deposited in the malacological collection of the Museu de Zoologia da Universidade de São Paulo (MZSP; São Paulo, Brazil) and our team has been steadily studying it over the past years. Those efforts are leading to an increase in the amount of information on cave-dwelling mollusks (e.g.; Simone 2012, 2013; Salvador et al. 2016, 2017; Simone et al. 2020). This increase in studies is very welcome, both from the perspectives of mollusk taxonomy (Salvador 2019b) and of environmental protection, given that cave ecosystems are usually fragile but harbor a reasonable number of endemic species (Trajano 2000; Gallão \& Bichuette 2012; Weigand 2013).

Some of those expeditions were undertaken by Dr. Bichuette to cave systems in the municipality of Presidente Olegário, Minas Gerais state, SE Brazil (September/2012 to June/2014). That karst region is famous for its multiple calcareous caves (Secutti \& Buchuette 2013) and, amidst a wealth of specimens of varied taxa, Dr. Bichuette's team collected many terrestrial and a few freshwater snails. No surveys of the molluscan fauna have been published from that locality so far, so the material they collected brings new information. We study those specimens herein, reporting twenty-five species, some of which are new records for Minas Gerais state.

\section{Material and Methods}

All the material studied here was collected by Maria Elina Bichuette and her team (G.F. Damasceno, J.S. Gallo, L.P.A. Resende, I.A. Ribeiro, and T. Zepon) and is deposited in the MZSP. All the specimens were collected in calcareous caves in the municipality of Presidente Olegário, Minas Gerais state, SE Brazil (Figure 1).

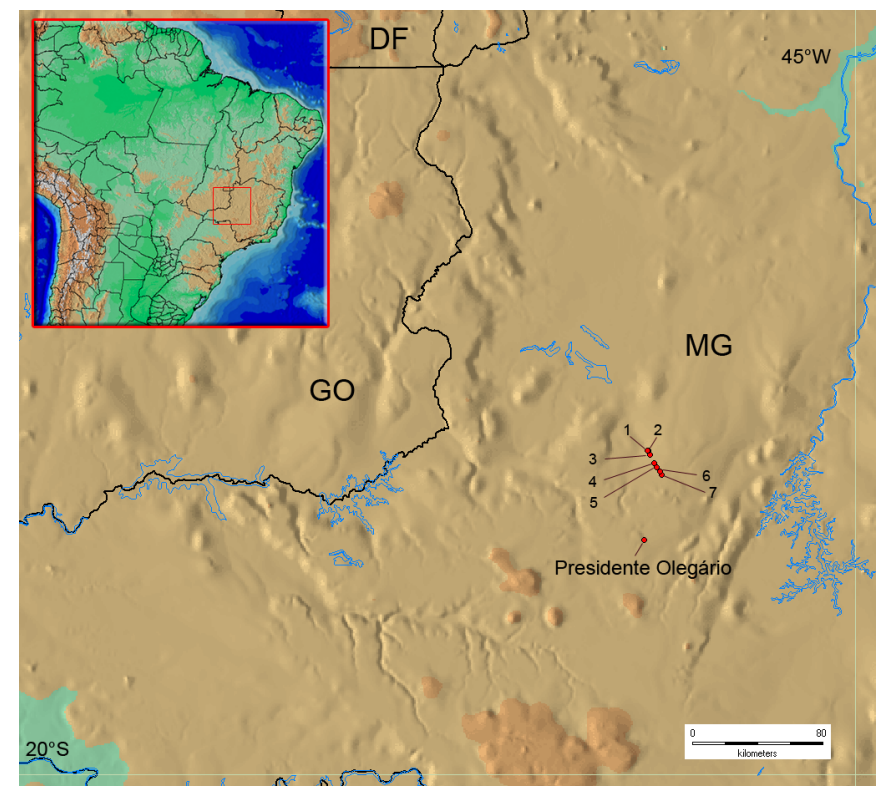

Figure 1. Map showing the municipality of Presidente Olegário in Minas Gerais state, SE Brazil, and the caves in the area: 1, Lapa Arco da Lapa; 2, Lapa da Fazenda São Bernardo; 3, Lapa da Juruva; 4, Lapa do Moacir; 5, Lapa Vereda da Palha; 6, Lapa Zé de Sidinei; 7, Toca do Charco. Abbreviations: DF, Distrito Federal; GO, Goiás state; MG, Minas Gerais state.

Presidente Olegário is located in the southern Alto São Francisco Basin, being inserted into the domains of the Cerrado Biome. The climate is tropical, semi-humid, with four to five months of drought (Nimer 1989). The karst of the region's landscape is rich with calcareous caves (Secutti \& Buchuette 2013). Seven different caves were surveyed and collection took place in four instances, covering the whole seasonal range: September/2013, and January, April, and June/2014 (Table 1).

The material comprised both empty shells and a few animals collected live; the latter were preserved in ethanol $70 \%$. For each collection effort, the time of active search used was always the same for each cave, according to the cave's size. Table 1 presents a list with all caves, alongside additional information on each.

Table 1. List of all caves in the municipality of Presidente Olegário, Minas Gerais state, Brazil, where the present material was collected.

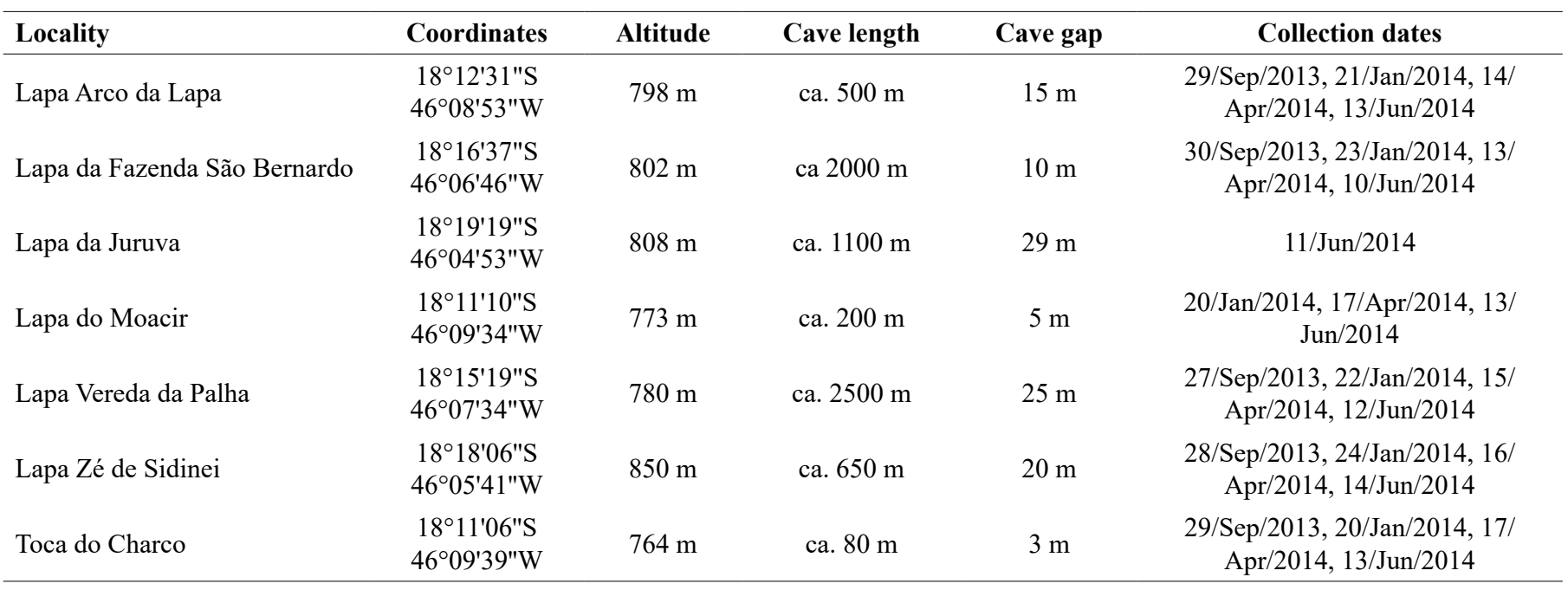


Identification was conducted based on the original descriptions (and type material whenever possible), the catalog of Simone (2006), further taxonomic literature, and additional comparative material (preferably from Minas Gerais state when possible) housed in the collection of the MZSP. Selected specimens were analyzed under SEM in the Staatliches Museum für Naturkunde Stuttgart (SMNS, Stuttgart, Germany). Some specimens (either juvenile or fragmentary) could not be identified beyond genus or even family level (Table 1).

The following abbreviations are used herein. Shell dimensions: $\mathbf{H}$, shell height (parallel to coiling axis); D, greatest shell width (perpendicular to $\mathrm{H}$ ); $\mathbf{h}$, aperture height (maximum length parallel to coiling axis); d, greatest width of aperture (maximum width perpendicular to coiling axis). Measurements were made with a digital caliper or, for minute shells, with the aid of computer software (Leica Application Suite [LAS] v.3.8.0 and ImageJ). Material: sh, empty shell(s); spm, specimen(s) collected live, ethanol-preserved. Caves: AdL, Lapa Arco da Lapa; FSB, Lapa da Fazenda São Bernardo; Jur, Lapa da Juruva; Moa, Lapa do Moacir; TdC, Toca do Charco; VdP, Lapa Vereda da Palha; ZdS, Lapa Zé de Sidinei. Cave zones: EP, epigean; EZ, entrance zone; TZ, twilight zone; DZ, dark (aphotic) zone.

\section{Results}

The complete list of species, the cave(s) (and the cave zone) where each occurs, and a relation of all the studied material are reported in Table 2. Species that require further discussion (i.e., those with new records for Minas Gerais state) are addressed below and figured (Figure 2), arranged according to the classification of Bouchet et al. (2017). The other species (i.e., not new records for Minas Gerais) are, nevertheless, recorded here for the first time from these caves.

\section{Neritimorpha \\ Family Helicinidae \\ Genus Alcadia Gray, 1840 \\ Alcadia iheringi Wagner, 1910 \\ Figure $2 \mathrm{~A}-\mathrm{C}$}

Alcadia iheringi Wagner, 1910: 354, pl. 70, figs. 7-8; Morretes, 1949: 63; Salgado \& Coelho, 2003: 151; Simone, 2006: 42, fig. 36; Agudo-Padrón, 2008: 151; Agudo-Padrón, 2012: 40; Agudo-Padrón, 2014: 10; Birckolz et al., 2016: table 1; Salvador et al., 2016: 61, figs. 2-4; Zepon \& Bichuette, 2017: 5.

Alcadia (Alcadia) iheringi: Haas, 1959: 365.

Type locality. Nova Teutônia, Santa Catarina state, Brazil.

Previously known distribution. Type locality; caves in Alto Ribeira State Park, São Paulo state.

New records. Presidente Olegário: in caves "Lapa da Fazenda São Bernardo" and "Lapa Zé de Sidinei". The present record extends the species range ca. $700 \mathrm{~km}$ to the northeast (ca. $650 \mathrm{~km}$ to the north).

Identification. Small conic-globose helicinid shell, with comparatively (among congeners) small and circular aperture.

Genus Helicina Lamarck, 1799

Helicina sordida King, 1832

Figure 2D-F
Helicina sordida King, 1832: 339; Pfeiffer, 1852: 622; Hupé, 1857: 62; Martens, 1867: 8; Salgado \& Coelho, 2003: 152; Simone, 2006: 40, fig. 30 .

Type locality. Rio de Janeiro, Brazil.

Previously known distribution. Rio de Janeiro (uncertain if state or city).

New records. Presidente Olegário: in cave "Lapa do Moacir". The present record extends the species range at least $400 \mathrm{~km}$ to the northwest.

Identification. Wide helicinid shell with prominent keel on body whorl; aperture D-shaped, laterally elongated, with strongly thickened peristome.

\section{Stylommatophora \\ Superfamily Achatinoidea Family Ferussaciidae \\ Genus Cecilioides Férussac, 1814 \\ Cecilioides consobrina (d'Orbigny, 1841)}

Figure 2G

Achatina consobrina d'Orbigny 1837: 89, pl. 11 bis, figs. 10-12; d'Orbigny, 1841: 170.

Achatina pygmaea Pfeiffer, 1847: 148.

Cecilioides (Caecilianopsis) consobrina: Pilsbry, 1909-1910: 39, pl. 5, figs. 81-82; Hylton Scott 1948: 254; Schade, 1965: 2014; Fernandez \& Castellanos, 1973: 271.

Cecilioides consobrina: Richards \& Hummelinck, 1940: 8; Morretes, 1949: 131; Wurtz, 1950: 107; Parodiz 1957: 131; Altena, 1960: 50; Salgado \& Coelho, 2003: 154; Simone, 2006: 183, fig. 666; Aguirre et al. 2007: 10, fig. 4.5; Míquel et al., 2007: 114; Oroño et al., 2007: 21; Míquel \& Aguirre 2011: 109, fig. 8; Salvador et al., 2017: 139, figs. 13-14; Salvador et al., 2018: 114, fig. 9H-I.

Cecilioides (Karolus) consobrina: Figueiras, 1963: 87; Quintana, 1982: 80; Míquel \& Herrera, 2014: 122.

Cecilioides consobrina consobrina: Ramírez et al, 2003: 276.

Type locality. Cuba, near Matanzas.

Previously known distribution. From Mexico (C. consobrina veracrucensis (Crosse \& Fischer, 1877)) to Argentina (e.g., Sandoval 1997; Miquel et al. 2007).

New records. Presidente Olegário: in cave "Lapa da Fazenda São Bernardo". Despite this species being widely distributed, this is, up to our knowledge, the first specific record from Minas Gerais state.

Identification. Minute smooth glossy bullet-like shell, with long and narrow aperture.

\author{
Superfamily Scolodontoidea \\ Family Scolodontidae \\ Genus Entodina Ancey, 1887 \\ Entodina gionensis Morretes, 1940 \\ Figure 2H-J
}

Entodina gionensis Morretes, 1940: 257, pl. 1, figs. 1-4; Morretes, 1949: 138; Simone, 2006: 223, fig. 849; Agudo-Padrón, 2008: 164; Agudo-Padrón, 2014: 18; Birckolz et al., 2016: table 1; Salvador et al., 2016: 64, figs. 16-18.

Type locality. Vamiranga Shell Mound, Iguape municipality, São Paulo state, Brazil. 
Salvador, R.B. et al.

Table 2. List of all species found, with information on locality, cave zone inhabited by the species, whether it is a new occurrence for Minas Gerais state, and catalog number of the MZSP collection. Classification of the genus Lilloiconcha Weyrauch, 1965 in the newly-recognized family Cystopeltidae follows Salvador et al. (2020). Abbreviations: Caves: AdL, Lapa Arco da Lapa; FSB, Lapa da Fazenda São Bernardo; Jur, Lapa da Juruva; Moa, Lapa do Moacir; TdC, Toca do Charco; VdP, Lapa Vereda da Palha; ZdS, Lapa Zé de Sidinei. Cave zones: EP, epigean; EZ, entrance zone; TZ, twilight zone; DZ, dark (aphotic) zone.

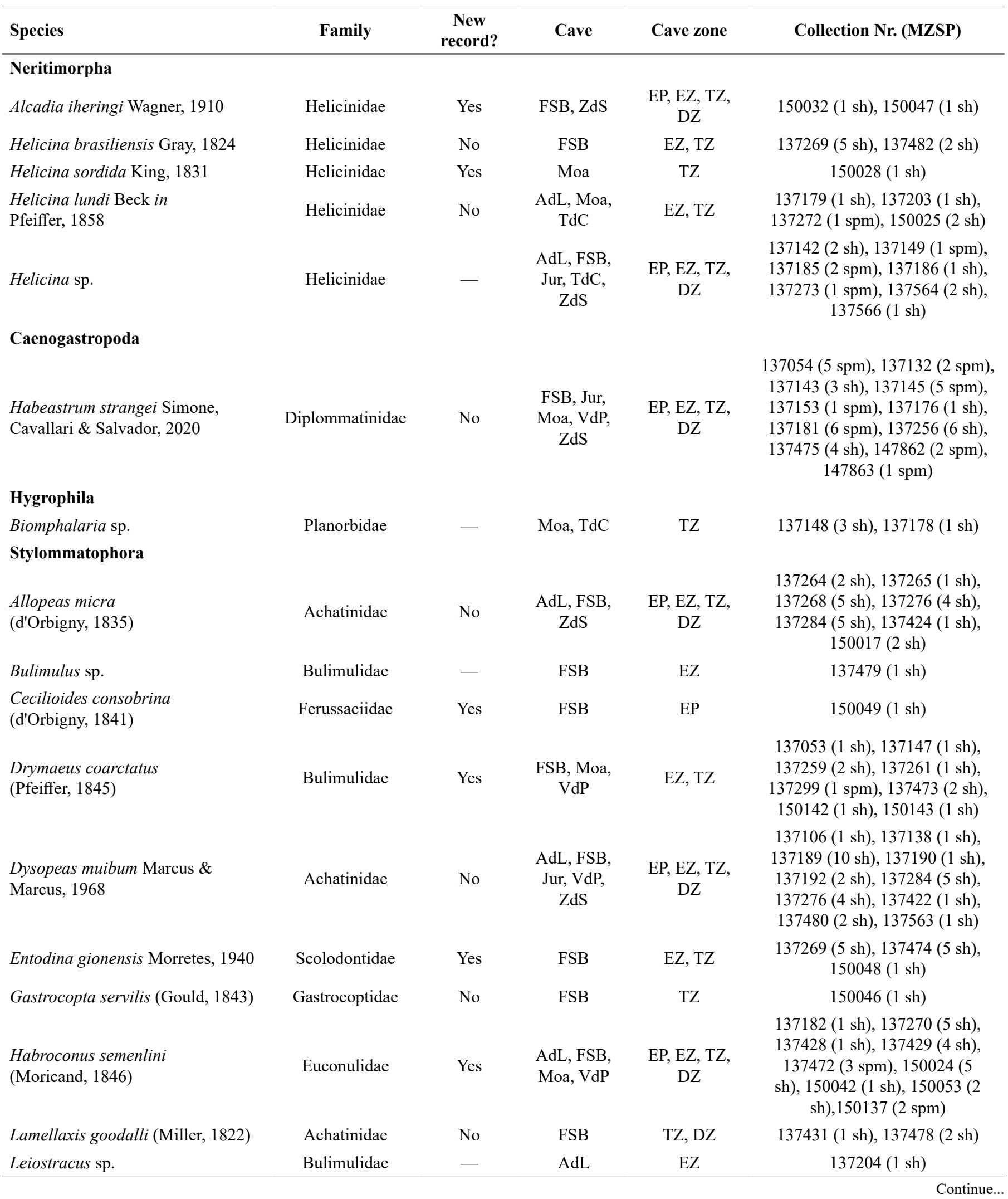


Continuation...

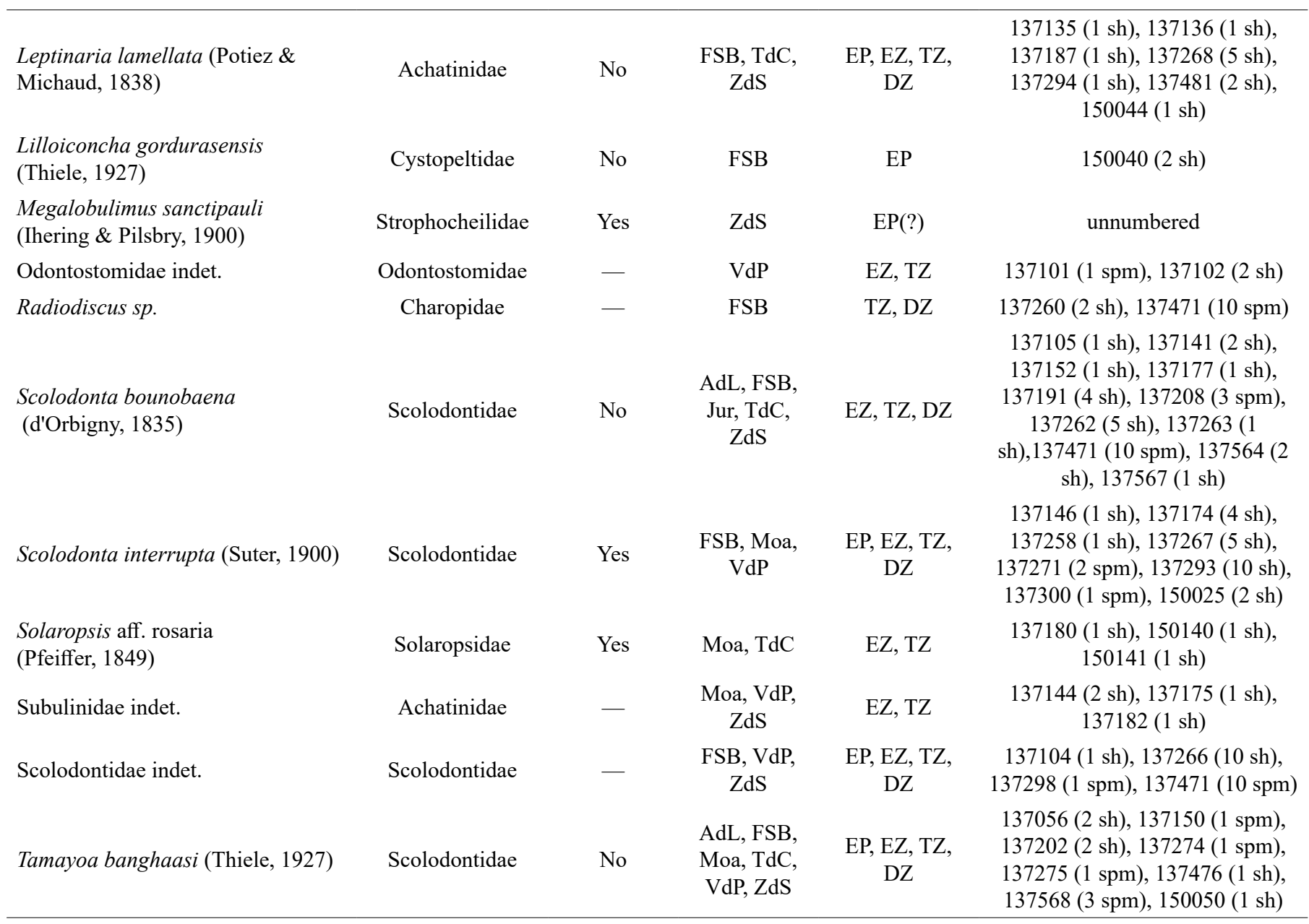

Previously known distribution. Known only from type locality in São Paulo state (Simone 2006). Outside of São Paulo, it has been reported from various municipalities in Santa Catarina state (AgudoPadrón 2008), but those remain unconfirmed (Salvador et al. 2016).

New records. Presidente Olegário: in cave "Lapa da Fazenda São Bernardo". The present record extends the species distribution ca. 700 to the north.

Identification. Discoid shell with flattened spire, sculptured by strongly sinuous ribs; aperture with strong parietal-columellar barrier and a marked palatal tooth. The present specimens have a slightly less developed parietal-columellar fold than typical E. gionensis.

Genus Scolodonta Doering, 1875

Scolodonta interrupta (Suter, 1900)

Figure $2 \mathrm{~K}-\mathrm{L}$

Streptaxis interruptus Suter, 1900: 331, pl. 3, fig. 5.

Scolodonta interrupta: Pilsbry, 1900: 385, pl. 12, figs. 6-8; Gude, 1902: 240; Kobelt, 1906: 69, pl. 51, figs. 21-23; Morretes, 1949: 166; Quintana, 1982: 104; Salgado \& Coelho, 2003: 170; Simone, 2006: 225, fig. 856; Salvador et al., 2016: 65, figs. 23-25; Zepon \& Bichuette, 2017: 5; Salvador, 2021: 64, figs. 4-6.
Type locality. Brazil, São Paulo state, Perus.

Previously known distribution. Known only from type locality (Salvador 2021). The report of Simone (2006) from Pará state is erroneous.

New records. Presidente Olegário: in caves "Lapa da Fazenda São Bernardo", "Lapa do Moacir" and "Lapa Vereda da Palha". The present record extends the species distribution ca. $500 \mathrm{~km}$ to the north.

Identification. Unsculptured scolodontid shell with slightly raised spire and small circular aperture lacking apertural barriers.

\section{Superfamily Rhytidoidea Family Strophocheilidae Genus Megalobulimus K. Miller, 1878 Megalobulimus sanctipauli (Ihering \& Pilsbry, 1900)}

Figure $2 \mathrm{M}-\mathrm{N}$

Strophocheilus oblongus var. sanctaepauli Ihering \& Pilsbry in Pilsbry, 1900: 390.

Strophocheilus (Borus) sanctaepauli: Pilsbry, 1901: 123, pl. 20, fig. 63.

Strophocheilus (Borus) sanctipauli: Pilsbry, 1902: v, xciv [emendation]. 


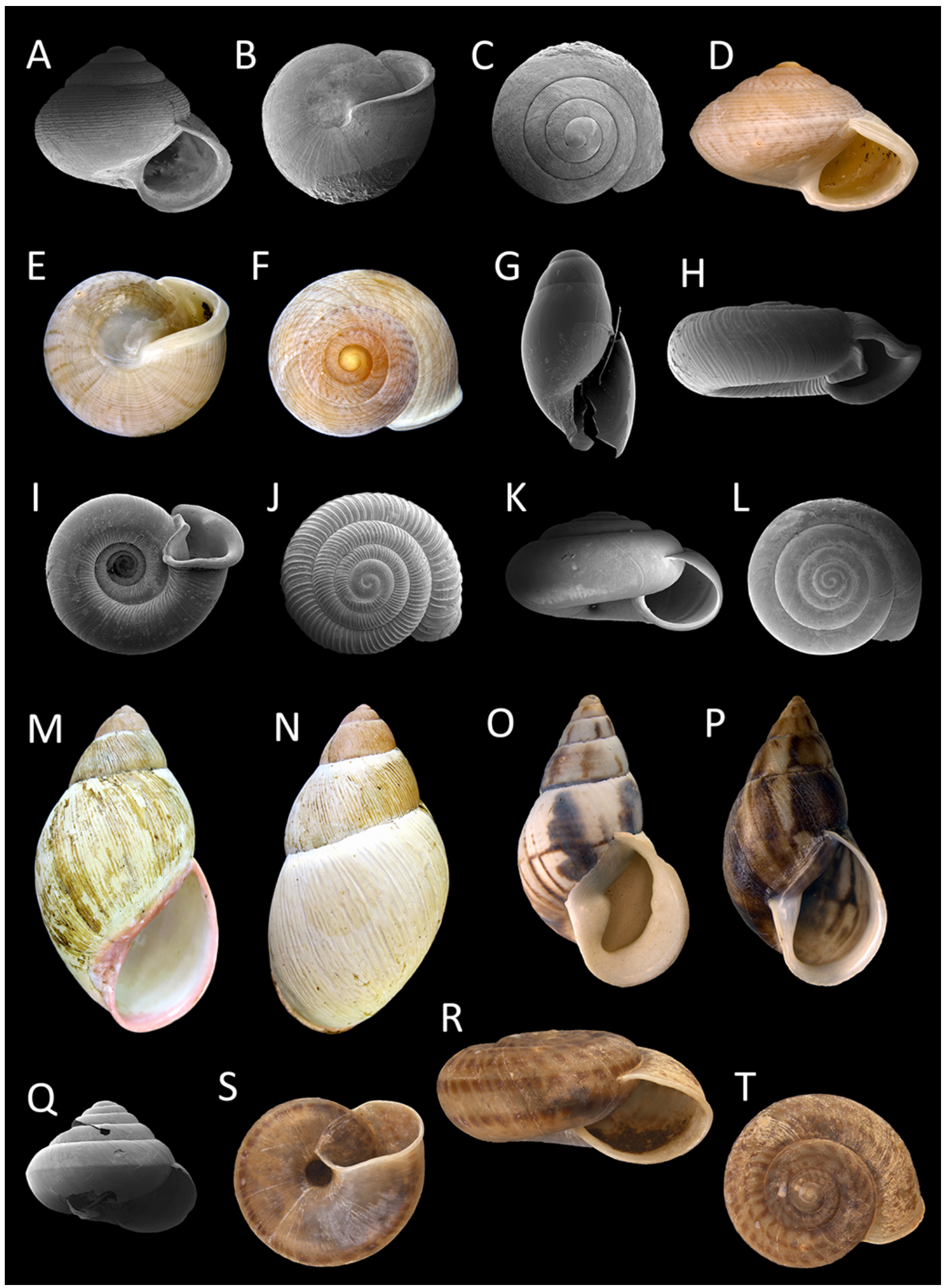

Figure 2. A-B. Alcadia iheringi (MZSP 150047; $\mathrm{H}=3.1 \mathrm{~mm}, \mathrm{D}=3.6 \mathrm{~mm})$. C. Alcadia iheringi (MZSP 150032; D = $3.5 \mathrm{~mm})$. D-F. Helicina sordida (MZSP 150028; $\mathrm{H}=5.3 \mathrm{~mm}, \mathrm{D}=7.8 \mathrm{~mm}$ ). G. Cecilioides consobrina (MZSP 150049; $\mathrm{H}=1.3 \mathrm{~mm}, \mathrm{D}=0.4 \mathrm{~mm})$. H-I. Entodina gionensis (MZSP 150048; H=1.6 mm, D = 4.0 mm). J. Entodina gionensis (MZSP 137471; D = $3.1 \mathrm{~mm}$ ). K-L. Scolodonta interrupta (MZSP unnumbered; $\mathrm{H}=4.1 \mathrm{~mm}, \mathrm{D}=7.0 \mathrm{~mm}$ ). M-N. Megalobulimus sanctipauli (MZSP unnumbered; $\mathrm{H}=11.5 \mathrm{~cm}, \mathrm{D}=6.5 \mathrm{~cm}$ ). $\mathbf{O}$. Drymaeus coarctatus, adult with thickened lip (MZSP $150142 ; \mathrm{H}=3.7 \mathrm{~cm}, \mathrm{D}=2.2 \mathrm{~cm}$ ). P. Drymaeus coarctatus, young adult with barely reflected lip (MZSP 150143; H =3.6 cm, D = 2.0 cm). Q. Habroconus semenlini (MZSP 150137; H=3.7 mm, D = $4.7 \mathrm{~mm}$ ). R-T. Solaropsis aff. rosaria (MZSP 150141; H = $10.0 \mathrm{~mm}, \mathrm{D}=19.4 \mathrm{~mm}$ ). 
Strophocheilus (Megalobulimus) sanctipauli: Bequaert, 1948: 137, pl. 13, fig. 7; Parodiz, 1957: 132; Fernández \& Castellanos, 1973: 276; Quintana, 1982: 85.

Strophocheilus sanctipauli: Morretes, 1949: 141; Cuezzo \& Drahg, 1995: 197.

Strophocheilus santipauli: Fernandez, 1978: 149, fig. 1.

Melalobulimus (Megalobulimus) sanctipauli: Morretes, 1953: 68.

Megalobulimus sanctipauli: Abbott, 1989: 76, textfig.; Salgado \& Coelho, 2003: 158; Simone, 2006: 219, fig. 831; Beltramino et al., 2012: 19, fig. 1; Beltramino, 2013: 469. Beltramino et al., 2015: 3, fig. 1; Zepon \& Bichuette, 2017: 5.

Type locality. Brazil, São Paulo state, Botucatu municipality.

Previously known distribution. Brazil (São Paulo and Paraná states), Paraguay (Canindeyú and Alto Paraná departments), Argentina (Missiones and Corrientes provinces) (Beltramino 2013). Unpublished data also record the species in the two southernmost states of Brazil: Santa Catarina and Rio Grande do Sul (J.H. Fontenelle pers. comm. 2016).

New records. Presidente Olegário: in cave "Lapa Zé de Sidinei". The present record extends the species range ca. $550 \mathrm{~km}$ to the northeast (ca. $500 \mathrm{~km}$ to the north).

Identification. Relatively tall and non-bulbous spire in comparison with congeners, with suture running almost perpendicular to shell axis.

\section{Superfamily Orthalicoidea Family Bulimulidae \\ Genus Drymaeus Albers, 1850 \\ Drymaeus coarctatus (L. Pfeiffer, 1845) \\ Figure 2O-P}

Bulimus coarctatus Pfeiffer, 1845: 73; Pfeiffer, 1848: 90; Pfeiffer, 1854: 80, pl. 22, figs. 22-23; Hupé, 1857: 56, pl. 10, fig. 4; Pfeiffer, 1858: 166.

Drymaeus coarctatus: Pilsbry, 1898: 195, pl. 28, figs. 17-20; Morretes, 1943: 117; Breure, 1979: 108; Salgado \& Coelho 2003: 161; Simone, 2006: 136, fig. 445: Zepon \& Bichuette, 2017: 5.

Drymaeus (Mormus) coarctatus: Morretes, 1949: 150.

Drymaeus (Drymaeus) coarctatus: Breure \& Eskens, 1981: 16, pl. 5, fig. 5; Breure \& Ablett, 2014: 5; 46, fig. 37F-H.

Kora terrea Simone, 2015: 51, figs. 1-5.

Kora iracema Simone, 2015: 54, figs. 15-20.

Drymaeus iracema: Salvador \& Simone, 2016: 3; Birckolz et al., 2016: 136, fig. 14.

Drymaeus terreus: Salvador \& Simone, 2016: 3; Birckolz et al., 2016: 138, fig. 15.

Type locality. Brazil (Pilsbry, 1898).

Previously known distribution. Reported only from the municipality of Lussanvira, Pereira Barreto, São Paulo state (Morretes 1943, 1949; Simone 2006).

New records. Presidente Olegário: in caves "Lapa da Fazenda São Bernardo", "Lapa do Moacir", "Lapa Vereda da Palha", as well as in Povoado de Galena, $18^{\circ} 25^{\prime}$ 'S $46^{\circ} 25^{\prime}$ 'W (type locality of Kora terrea). It was also recorded in the Gruta do Morro dos Tapuias, $12^{\circ} 30^{\prime} \mathrm{S}$ $45^{\circ} 03^{\prime} \mathrm{W}$, municipality of São Desidério, Bahia state (type locality of K. iracema). The present record extends the species range ca. $1,000 \mathrm{~km}$ to the northeast (ca. $750 \mathrm{~km}$ to the north).
Identification. Bulimoid shell; reticulate protoconch; aperture with reflected and strongly thickened peristome, unique among the congeners in Brazil. The peristome thickens with age, as younger specimens have a "typical" Drymaeus-like appearance (Figure 2P).

Remarks. Drymaeus iracema (Simone, 2015) and D. terreus (Simone, 2015) were originally described as troglobiont species classified in the genus Kora Simone, 2012. The former is known from São Desidério municipality in Bahia state and the latter, from Presidente Olegário municipality, in Minas Gerais state. Salvador \& Simone (2016) argued that they belonged in Drymaeus Albers, 1850 based on the reticulate protoconch sculpture. Further conchological features such as the strongly expanded peristome, the straight profile of the spire, and the upright columellar region, allow us to propose here that both D. iracema (holotype MZSP 104964) and D. terreus (holotype MZSP 106215), conchologically indistinguishable from one another, are junior synonyms of Drymaeus coarctatus (lectotype NHMUK 1975560; Simone 2006: fig. 445; Breure \& Ablett 2014: fig. 37F-H).

Drymaeus coarctatus is thus widely distributed in eastern Brazil: from western Bahia state (São Desidério municipality), through Minas Gerais state (Presidente Olegário municipality, and newly reported specimens MZSP 152050, 152078, and 152091 from the municipalities of Paracatu and Unaí) and Espírito Santo state (newly reported specimen, USNM IZ530536, from the collection of the Smithsonian National Museum of Natural History, Washington, D.C., USA), to northern São Paulo state (Simone 2006: Lussanvira, an old railway station in Pereira Barreto municipality).

The shell of this species can present tooth-like thickenings on the palatal and basal regions of the peristome, as well as a more marked fold on the apical end of the columellar region (e.g., lectotype and specimen USNM IZ530536). All these structures supposedly develop as the individual grows older and deposits more shell material on the peristome. The shell can have a flame-like coloration pattern of the periostracum (MZSP 106215) or a pattern composed of several brown narrow spiral stripes (USNM IZ530536). Such intraspecific variation in shell color is well documented in other species of Drymaeus (e.g., Salvador et al. 2018).

\section{Superfamily Trochomorphoidea Family Euconulidae \\ Genus Habroconus Crosse \& P. Fischer, 1872 \\ Habroconus semenlini (Moricand, 1846) \\ Figure 2Q}

Helix Semen-lini Moricand, 1846: 149, pl. 5, fig. 17; Pfeiffer, 1846: 457, 1848: 31, 1853: 32; Reeve, 1854: pl. 112, fig. 637; Hupé, 1857: 14. Helix (Hyalina) semen lini: Albers, 1860: 73.

Hyalina semen lini: Heynemann, 1868: 106; Clessin, 1888: 166.

Hyalina (Conulus) semen lini: Martens, 1868: 175.

Conulus semen lini: Ihering, 1894: 38.

Guppya semen-lini: Ancey, 1897: 9.

Guppya seminlini: Pilsbry, 1900: 386.

Vitrea semen lini: Suter, 1900: 331.

Habroconus (Pseudoguppya) semen-lini: Haas, 1953: 205, 1959: 365.

Habroconus (Pseudoguppya) semenlini: Baker, 1928: 12; Morretes, 1949: 137; Figueiras, 1963: 87; Schade, 1965: 214; Fernandez \& Castellanos, 1973: 274; Quintana, 1982: 79. 
Habroconus semenlini: Klappenbach, 1967: 42; Agudo-Padrón, 2008: 166; Santos et al., 2010: 516; Agudo-Padrón, 2014: 18.

Habroconus semenline: Salgado \& Coelho, 2003: 154.

Pseudoguppya semenlini: Salvador et al., 2016: 65; Salvador et al., 2018: 124, figs. 14A-C; Zepon \& Bichuette, 2017: 5; Salvador, 2019a: 95; Silva et al., 2019: 184, fig. 4A-C.

Type locality. Bahia state, Brazil.

Previously known distribution. Brazil (Alagoas, Bahia, Rio de Janeiro, São Paulo, Paraná, Santa Catarina, and Rio Grande do Sul states), Paraguay, Uruguay, Argentina (Silva et al. 2019).

New records. Presidente Olegário: in caves "Lapa Arco da Lapa" and "Lapa da Fazenda São Bernardo", "Lapa do Moacir" and "Lapa Vereda da Palha". The present record fills a gap in the species' distribution.

Identification. Typical euconulid shell; body whorl with marked angulation and relatively tall compared to congeners; broad D-shaped aperture.

\section{Superfamily Sagdoidea \\ Family Solaropsidae \\ Genus Solaropsis Beck, 1837 \\ Solaropsis aff. rosaria (L. Pfeiffer, 1849)}

Figure $2 \mathrm{R}-\mathrm{T}$

Solaropsis rosarium [sic]: Salvador et al., 2015: 68, figs. 7-9.

Type locality. Banks of the Amazon River (Pfeiffer, 1853; Pilsbry, 1933).

Previously known distribution. From Amazonas to Mato Grosso do Sul, Brazil (Salvador et al., 2015). Previous reports from Suriname and "New Granada" have been considered spurious (Pilsbry, 1933).

New records. Presidente Olegário: in caves "Lapa do Moacir" and "Toca do Charco". The present record, if confirmed, would mean an increase of ca. $300 \mathrm{~km}$ in the species' distribution towards the southeast.

Identification. The present specimens do not exactly match the species $S$. rosaria, typically known from the Amazon biome in South America. However, they are indistinguishable from the specimens from Tocantins state, in central Brazil, that Salvador et al. (2015) called $S$. rosarium [sic]. The present specimens thus belong to the same species as those of Salvador et al. (2015), but their identity remains elusive for now.

The specimens are also reminiscent of $S$. derbyi Ihering, 1900 from São Paulo state, southeastern Brazil. However, that species is poorly defined and its type specimen is badly preserved (Simone 2006: fig. 937).

The taxonomy of Solaropsis in Brazil is riddled with poorly-defined species, a few potentially invalid names, several potential synonyms, unrecognized intraspecific variability of shell morphology, and almost no knowledge of anatomical features, DNA, and basic biology (Cuezzo 2002; Calcutt et al. 2020). As such, proper identification of the present specimens will have to wait until a better definition of species boundaries in the genus is in place.

Remarks. This species has been lately classified in the genus Psadara Miller, 1878 (e.g., Simone 2006); however, a recent molecular analysis has confirmed that Psadara is a synonym of Solaropsis (Calcutt et al. 2020).

\section{Discussion}

Orthalicoidea is usually the most diverse group of land snails in any sample of mollusks taken in Brazil (Salvador 2019b). However, as already pointed out by Salvador et al. (2016), this does not seem to hold for the troglofauna, in which Subulininae and Scolodontidae are represented by a more diverse assembly of species among the stylommatophorans. In the present material, only four orthalicoid species were found (and only in the epigean and the entrance zone of the caves; Table 2). Meanwhile, several subulinine and scolodontid taxa were recovered from the epigean to the dark aphotic zone of the caves (Table 2). From all species reported herein, only Habeastrum strangei is a known cave endemic (Simone et al., 2020); all the others have wider distributions in non-cave environments.

Moreover, a curiously high number (four) of helicinids species was found in the material, including living specimens in the aphotic zones of the caves (Table 2). Our previous studies on cavern snails have always been poor on helicinid specimens (e.g., Salvador et al. 2016, 2017). Neotropical helicinids are typically considered arboreal species in the literature (e.g., Richling 2004), but here it can be seen that they might inhabit other habitats as well.

From the caves studied here, almost all of them have little left of the original Cerrado vegetation in their surroundings; the place was cleared to give way to pasture or agriculture and only a couple of meters of native vegetation remains in the entrance area of each cave (T. Zepon, personal communication 2016). Only a single cave ("Lapa Arco da Lapa") has a larger surrounding area of native vegetation (ca. $100 \mathrm{~m}$ ) (T. Zepon, personal communication 2016). That does not seem to affect the species composition of that cave, as almost all the species found in Lapa Arco da Lapa were also recorded from other caves; the single exception is Leiostracus sp., an arboreal snail found in the epigean area there (Table 2).

Several of the species reported here are first records for Minas Gerais state (Results section; Table 2). This report extends the geographical distribution of some species, while simply filling "distribution gaps" of others. Moreover, the present records are especially important, as they are among the few dealing with molluscan troglofauna in the region and Brazil as a whole. Land snails are considered the most threatened group of animals (Lydeard et al. 2004; Régnier et al. 2008) and many of them inhabit, and could likely be endemic to, caves (Simone \& Moracchioli 1994; Simone 2013; Weigand 2013; Salvador 2019b).

The vast majority of caves in Brazil completely lack legal protection. Better known geographical distributions improve arguments for conservation, as the Brazilian legislation states that a cave must be protected if it harbors rare or endemic species (Campos-Filho et al. 2014). Hence the great importance of troglofaunal inventories, as delays in ensuring proper protection to those habitats might result in irreparable biodiversity loss.

\section{Acknowledgements}

We are deeply grateful to Maria E. Bichuette (UFSCar) and her team (especially to Bruno G.O. Monte and Tamires Zepon) for providing the material studied here and information on the collection localities; to Karin Wolf-Schwenninger and Christina G. Martin (SMNS) for the SEM images; to Jonathan Ablett and Harry Taylor (NHMUK) and Robert Hershler (USNM) for sharing photographs and information on 
the specimens of Drymaeus coarctatus in the collections under their care; and to José H. Fontenelle (Orquidário Municipal de Santos, Brazil) for the information on Megalobulimus sanctipauli; to Cascon-Helena Matthews and two anonymous reviewers for their helpful comments and suggestions. This work was partly supported by a doctoral grant from Conselho Nacional de Desenvolvimento Científico e Tecnológico (CNPq, Brazil, proc. \#245575/2012-0) to RBS. RBS also acknowledges the support of SMNS for SEM analysis.

\section{Author Contributions}

Rodrigo B. Salvador: conceptualized the study; led the taxonomic study and writing of the manuscript.

Fernanda S. Silva: led the taxonomic study and writing of the manuscript.

Daniel C. Cavallari: contributed to the study and manuscript writing.

Luiz Ricardo L. Simone: contributed to the study and manuscript writing.

\section{Conflicts of Interest}

The authors declare that they have no conflict of interest related to the publication of this manuscript.

\section{References}

Abbott RT (1989) Compendium of land shells. American Malacologists, Melbourne, $240 \mathrm{pp}$.

Agudo-Padrón AI (2008) Listagem sistemática dos moluscos continentais ocorrentes no estado de Santa Catarina, Brasil. Comunicaciones de la Sociedad Malacológica del Uruguay 9 (91): 147-179.

Agudo-Padrón AI (2012) Nuevos aportes a la lista sistemática de moluscos continentales ocorrentes em el Estado de Santa Catarina, Brasil. Amici Molluscarum 20 (1): 35-42.

Agudo-Padrón AI (2014) Inventario sistemático de los moluscos continentales ocurrentes en el Estado de Santa Catarina, Brasil/ Inventário sistemático dos moluscos continentais ocorrentes no Estado de Santa Catarina, Brasil. BIOMA 2 (21): 6-23.

Aguirre ML, Miquel SE, González CA, Kröhling D, Zucol AF, Brea M, Eastoe C (2007) Malacofauna continental holocena y paleoambientes em Villa Valle María (Diamante, Entre Ríos, Argentina). Geobios 44 (1): 1-17. https://doi. org/10.1016/j.geobios.2010.06.003

Albers JC (1860) Die Heliceen. Leipzig, Verlag von Wilhelm Engelmann, 359 pp.

Altena COvR (1960) On a small collection of land Mollusca of Surinam (Dutch Guyana). Basteria 24 (4): 48-51.

Ancey CF (1897) Viaggio del Dott. Alfredo Borelli nel chaco boliviano e nella Repubblica Argentina XI. Resultats malacologiques accompagnés d'une notice sur les espèces précédemment recueillies par ce voyageur. Bollettino dei Musei di Zoologia ed Anatomia Comparada dela R. Universitá diTorino 12 (309): 1-22.

Baker F (1913) The land and freshwater mollusks of Stanford Expedition to Brazil. Proceedings of the Academy of Natural Sciences of Philadelphia 65 (1914): 618-672.

Baker HB (1928) Minute American Zonitidae. Proceedings of the Academy of Natural Sciences of Philadelphia 80: 1-44.

Baker HB (1945) Some American Achatinidae. The Nautilus 58: 84-92. https:// doi.org/10.5962/bhl.part.27492

Baker HB (1961) Beckianum - new genus. The Nautilus 75: 84. https://doi. org/10.5962/bhl.part.25950

Beltramino AA (2013) Distribution of Megalobulimus sanctipauli (Ihering and Pilsbry, 1900) (Gastropoda: Megalobulimidae) in South America. Check List 9 (2): 469-471. https://doi.org/10.15560/9.2.469

https://doi.org/10.1590/1676-0611-BN-2020-1169
Beltramino AA, Vogler RE, Rumi A (2012) Megalobulimus sanctipauli (Ihering y Pilsbry, 1900): antecedentes de la especie. Amici Molluscarum 20 (2): 19-24.

Beltramino AA, Vogler RE, Gregoric DEG, Rumi A (2015) Impact of climate change on the distribution of a giant land snail from South America: predicting future trends for setting conservation priorities on native malacofauna. Climatic Change 131 (4): 1-13. http://dx.doi.org/10.1007/ s10584-015-1405-3

Bequaert JC (1948) Monograph of the Strophocheilidae, a neotropical family of terrestrial mollusks. Bulletin of the Museum of Comparative Zoology 100 (1): 1-210.

Bichuette ME, Trajano E (1999) Light reaction, spontaneous and feeding behaviour in epigean and cave gastropods, Potamolithus spp., from Upper Ribeira karst area, southeastern Brazil (Mollusca: Gastropoda: Hydrobiidae). Mémoires de Biospéologie 26: 1-6.

Bichuette ME, Trajano E (2003) Population study of epigean and subterranean Potamolithus snails from southeast Brazil (Mollusca: Gastropoda: Hydrobiidae). Hydrobiologia 505: 107-117. http://doi.org./10.3897/ subtbiol.25.23778

Birckolz CJ, Salvador RB, Cavallari DC, Simone LRL (2016) Illustrated checklist of newly described (2006-2016) land and freshwater Gastropoda from Brazil. Archiv für Molluskenunde 145 (2): 133-150. https://doi.org/10.1127/ arch.moll/145/133-150

Bouchet P, Rocroi JP, Hausdorf B, Kaim A, Kano Y, Nützel A, Parkhaev P, Schrödl M, Strong EE (2017) Revised classification, nomenclator and typification of gastropod and Monoplacophoran families. Malacologia 61 (1-2): 1-526. https://doi.org/10.4002/040.061.0201

Breure ASH (1979) Systematics, phylogeny and zoogeography of Bulimulidae (Mollusca). Zoologische Verhandelingen 168: 1-215.

Breure ASH, Eskens AAC (1981) Notes on and descriptions of Bulimulidae (Mollusca, Gastropoda), II. Zoologische Verhandelingen 186: 1-111.

Calcutt J, Cuezzo MG, Jackson M, Salvador RB (in press). Phylogenetic relationships and classification of Solaropsidae (Gastropoda: Stylommatophora). Archiv für Molluskenkunde.

Campos-Filho IS, Araujo PB, Bichuette ME, Trajano E, Taiti S (2014) Terrestrial isopods (Crustacea: Isopoda: Oniscidea) from Brazilian caves. Zoological Journal of the Linnean Society 172: 360-425. https://doi.org/10.1111/ zoj. 12172

Clessin S (1888) Binnenmollusken aus Südbrasilien. Malakozoologische Blätter 10 (2): $165-174$.

Cuezzo MG (2002) On Solaropsis Beck: new anatomical data and its systematic position within the Helicoidea (Pulmonata: Stylommatophora). Papéis Avulsos de Zoologia 42 (3): 31-46

Cuezzo MG, Drahg F (1995) Moluscos depositados en la colección de la Fundación Miguel Lillo: Argentina. Acta Zoologica Lilloana 43 (1): 185-205.

Fernández D (1978) Nota sobre Strophocheilus sinistrales (Moll. Gastr.). Neotropica 24 (72): 149-150.

Fernandez D, Castellanos ZJA(1973) Clave generica de la malacofauna terrestre argentina. Revista del Museo de la Plata (Nueva Serie) 11 (107): 265-285.

Figueiras A (1963) Enumeracíon sistemática de los moluscos terrestres del Uruguay. Comunicaciones de la Sociedad Malacologica del Uruguay 1 (4): 79-96.

Gallão JE, Bichuette ME (2012) A lista de fauna ameaçada de extinção e os entraves para a inclusão de espécies - o exemplo dos peixes troglóbios brasileiros. Natureza \& Conservação 10 (1): 83-87.

Gude GK (1902) Synopsis of the genus Streptaxis and its allies. Proceedings of the Malacological Society of London 5: 201-244. https://doi.org/10.1093/ oxfordjournals.mollus.a065968

Haas F (1935) Kurze bemerkungen V (3): binnenschnecken aus verschiedenen teilen Brasiliens. Archiv für Molluskenkunde 67 (3): 109-111.

Haas F (1939) Zur Kenntnis der Binnen-Mollusken NO-Brasiliens. Senckenbergiana 21 (3-4): 254-278

Haas F (1953) Mollusks from Ilha Grande, Rio de Janeiro, Brazil. Fieldiana (Zoology) 34 
(20): 203-209.

Haas F (1959) Inland mollusks from Venezuela, southern Brazil and Peru. Fieldiana Zoology 39 (31): 363-371.

Heynemann DF (1868) Die Mundtheile einiger brasilianischen land-und süsswasserschnecken. Malakozoologische Blätter 15: 99-113.

Hupé MH (1857) Mollusques. In: Castelnau F (Ed.) Animaux nouveaux ou rares récueillis pendant l'expedition dans les parties centrales de l'Amerique du Sud, de Rio de Janeiro à Lima au Peru Tome Second. P. Bertrand, Paris, 1-96.

Hylton Scott MI (1948) Moluscos del noroeste argentino. Acta Zoológica Lilloana 6: 241-274.

Ihering H (1894) Uber binnen-conchylien der küstenzone von Rio Grande do Sul. Archiv für Naturgeschichte 60: 37-40.

Klappenbach MA(1967) La primeira lista de moluscos publicada em el Uruguay. Comunicaciones de la Sociedad Malacologica del Uruguay 2 (12): 41-44.

King PP (1832) Description of the Cirrhipeda, Conchifera and Mollusca, in a collection formed by the officers of H.M.S. Adventure and Beagle employed between the years 1826 and 1830 in surveying the southern coasts of South America, including the Straits of Magalhaens and the coast of Tierra del Fuego. Zoological Journal 5: 332-349.

Kobelt W (1906) Die Raublungenschnecken (Agnata). Zweite Abtheilung. Streptaxidae und Daudebardiidae. In: Küster HC, Kobelt W (Eds.) Systematisches Conchylien-Cabinet von Martini und Chemnitz. Ersten Bandes, Zwölfte Abtheilung. Bauer \& Raspe, Nuremberg, 1-211.

Lydeard C, Cowie RH, Ponder WF, Bogan AE, Bouchet P, Clark SA, Cummings KS, Frest TJ, Gargominy O, Herbert DG, Hershler R, Perez KE, Roth B, Seddon M, Strong EE, Thompson FG (2004) The global decline of nonmarine mollusks. BioScience 54: 321-330. https://doi.org/10.1641/00063568(2004)054[0321:TGDONM]2.0.CO;2

Maestrati P, Simone LRL, Bouchet P (2015) Moluscos (Mollusca) da Reserva Biológica de Pedra Talhada. In: Studer A, Nusbaumer L, Spichiger R (Eds.) Biodiversidade da Reserva Biológica de Pedra Talhada (Alagoas, Pernambuco - Brasil). Boissiera 68: 163-172.

Martens Ev (1867) Die preussische Expedition nach Ost-Asien: nach amtlichen Quellen - Landschnecken von Rio Janeiro. Zoologischer Theil: 6-9.

Martens Ev (1868) Ueber südbrasilianische land-und süsswassermollusken. Malakozoogische Blätter 15: 169-217.

Miquel SE, Aguirre ML (2011) Taxonomía de los gasterópodos terrestres del Cuaternario de Argentina. Revista Española de Paleontología 26 (2): 101-133.

Miquel SE, Herrera HW (2014) Catalogue of terrestrial gastropods from Galápagos (except Bulimulidae and Succineidae) with description of a new species of Ambrosiella Odhner (Achatinellidae). Archiv für Molluskenkunde 143 (2): 107-133. https://doi.org/10.1127/arch.moll/1869-0963/143/107-133

Miquel SE, Tablado A, Sodor A (2007) Curaduría en la Colección Nacional de Invertebrados de Argentina: aportes a la biodiversidad y biogeografía de gasterópodos terrestres argentinos. Comunicaciones de la Sociedad Malacológica del Uruguay 9 (90): 113-115.

Moricard S (1836) Mémorie sur les coquilles terrestres et fluviatiles, envoyées de Bahia par M.J. Blanchet. Memoires de la Société de Physique et d'Histoire Naturelle de Genève 7 (2): 415-446.

Morretes FL (1943) Contribuição ao estudo da fauna brasileira de moluscos: resultados de uma pequena coleção de moluscos obtida pela excursão científica realizada pelo Instituto Oswaldo Cruz em outubro de 1938. Papéis Avulsos do Departamento de Zoologia 3 (7): 111-126.

Morretes FL (1949) Ensaio de catálogo dos moluscos do Brasil. Arquivos do Museu Paranaense 7: 1-216.

Morretes FL (1953) Adenda e Corrigenda ao Ensaio de Catálogo dos Moluscos do Brasil. Arquivos do Museu Paranaense 10: 37-76.

Nimer E (1989) Climatologia do Brasil. Instituto Brasileiro de Geografia e Estatística, Rio de Janeiro.

d'Orbigny A (1841-1845) Mollusques. In: de la Sagra R (Ed.) Histoire Physique, Politique et Naturelle de l'Ile de Cuba. A. Bertrand, Paris, 1: 1-208 (1841), 209-264 (1842); 2: 1-112 (1842); 113-380 (1847-1853); Atlas: pls. 1-29 (1842).
Oroño ES, Cuezzo MG, Romero F (2007) Land snail diversity in subtropical rainforest mountains (Yungas) of Tucumán, northwestern Argentina. American Malacological Bulletin 22 (1): 17-26. https://doi. org/10.4003/0740-2783-22.1.17

Parodiz JJ (1957) Catalogue of the land Mollusca of Argentina. The Nautilus 70: 127-135. https://doi.org/10.4002/040.056.0210

Pfeiffer L (1845) Descriptions of twenty-two new species of Helix, from the collections of Miss Saul-Watton Esq. and H. Cuming Esq. Proceedings of the Zoological Society of London 13: 71-75.

Pfeiffer L (1846) Symbolae ad historiam Heliceorum, Vol. 3, Cassell (T. Fischer), $100 \mathrm{pp}$.

Pfeiffer L (184) Diagnosen neuer Heliceen. Zeitschrift für Malakozoologie 4: 31-32, 81-84.

Pfeiffer L (1848) Monographia Heliceorum Viventium. Volumen Secundum. F.A. Brockhaus, Lipsiae. 594 pp.

Pfeiffer L (1850-1853) Die Schrirkelschnecken nebst den zunächst verwandten gattungen. Zweiter Teil. In: Küster HC, Kobelt W (Eds.) Systematisches Conchylien-Cabinet von Martini und Chemnitz. Ersten Bandes, Zwölfte Abtheilung. Bauer \& Raspe, Nuremberg, 1-284.

Pfeiffer L (1852) Monographia Pneumonopomorum Viventium. Cassellis-London, $\mathrm{i}-\mathrm{xvi}+439 \mathrm{pp}$.

Pfeiffer L (1854-1860) Novitates Conchologicae. Series prima. Mollusca extramarina. Beschreibung und Abbildung neuer order kritischer Land- und SüsswasserMollusken. Bd. 1. T. Fischer, Cassel.

Pfeiffer L (1856) Diagnosen neuer Landschnecken. Malakozoologische Blätter 3: $43-52$.

Pfeiffer L (1858) Literatur. Malakozoologische Blätter 5: 156-171.

Pilsbry HA (1897-1898) Manual of Conchology, Second Series. Pulmonata. Vol. 11. American Bulimulidae, Bulimulus, Neopetraeus, Oxychona, and South American Drymaeus. Academy of Natural Sciences of Philadelphia, Philadelphia.

Pilsbry HA (1900) New South American land shells. Proceedings of the Academy of Natural Sciences of Philadelphia 52: 385-394.

Pilsbry HA(1901-1902) Manual of Conchology, Second Series. Pulmonata. Vol. 14. Oriental Bulimoid Helicidae; Odontostominae; Cerionidae. Academy of Natural Sciences of Philadelphia, Philadelphia.

Pilsbry HA (1906) Manual of Conchology, Second Series. Pulmonata. Vol. 18. Achatinidae: Stenogyrinae and Coeliaxinae. Academy of Natural Sciences of Philadelphia, Philadelphia.

Pilsbry HA (1909-1910) Manual of Conchology, Second Series. Pulmonata. Vol. 20. Caecilioides, Glessula and Partulidae. Index to vols. XVI-XX. Academy of Natural Sciences of Philadelphia, Philadelphia.

Pilsbry HA(1933) Zoological results of the Mato Grosso Expedition to Brazil in 1931 - II Mollusca Proceedings of the Academy of Natural Sciences of Philadelphia 85: 67-76.

Quintana MG (1982) Catalogo preliminar de la malacofauna del Paraguay. Revista del Museo Argentino de Ciencias Naturales "Bernardino Rivadavia" (Zoologia) 11 (3): 61-158.

Ramírez R, Paredes C, Arenas J (2003) Moluscos del Perú. Revista de Biología Tropical 51 (3): 225-284.

Reeve LA (1854) Monograph of the genus Helix. Conchologia Iconica v. 7, Reeve, Behan, London, 210 pp.

Régnier C, Fontaine B, Bouchet P (2009) Not knowing, not recording, not listing: numerous unnoticed mollusk extinctions. Conservation Biology 23: 1214-1221. https://doi.org/10.1111/j.1523-1739.2009.01245.x

Richards HG, Hummelinck PW (1940) Land and freshwater mollusks from Margarita Island, Venezuela. Notula Nature 62: 1-16.

Richling I (2004) Classification of the Helicinidae: review of morphological characteristics based on a revision of the Costa Rican species and application to the arrangement of the Central American mainland taxa (Mollusca: Gastropoda: Neritopsina). Malacologia 45(2):195-440.Salgado NC, Coelho ACS (2003) Moluscos terrestres do Brasil (gastrópodes operculados ou não, exclusive Veronicellidae, Milacidae e Limacidae). Revista de Biología Tropical 51 (3): 149-189. 
Salvador RB (2019a) Brazilian, Uruguayan and Argentinian land snails in the collection of the Museum of New Zealand Te Papa Tongarewa. Tuhinga 30: 82-98.

Salvador RB (2019b) Land snail diversity in Brazil. Strombus 25: 10-20.

Salvador RB (2021) Type specimens of the South American terrestrial gastropods described by Henry Suter. Integrative Systematics 3: 61-68.

Salvador RB, Simone LRL (2015) Taxonomical study on a sample of land snails from Alcobaça (Bahia, Brazil), with description of a new species. Stuttgarter Beiträge zur Naturkunde A 8: 1-7.

Salvador RB, Simone LRL (2016) A new species of Kora from Bahia, Brazil (Gastropoda: Pulmonata: Orthalicoidea), with an emended diagnosis of the genus. Stuttgarter Beiträge zur NaturkundeA, 9(1): 1-7. https://doi.org/10.18476/ sbna.v9.a1

Salvador RB, Brook FJ, Shepherd LD,Kennedy M (2020) Molecular phylogenetic analysis of Punctoidea (Gastropoda, Stylommatophora). Zoosystematics and Evolution 96 (2): 397-410. https://doi.org/10.3897/zse.96.53660

Salvador RB, Cavallari DC, Simone LRL (2015) Taxonomical study on a sample of land snails from southeastern Tocantins state, Brazil, with description of a new species. Journal of Conchology 42: 67-78.

Salvador RB, Cavallari DC, Simone LRL (2016) Taxonomical study on a sample of land snails from Alto Ribeira State Park (São Paulo, Brazil), with description of a new species. Archiv für Molluskenkunde 145(1): 59-68. https://doi.org/10.1127/ arch.moll/1869-0963/145/059-068

Salvador RB, Cavallari, DC, Simone, LRL (2017) Taxonomical study on a sample of land and freshwater snails from caves in central Brazil, with description of a new species. Zoosystematics and Evolution 93 (1): 135-141. https://doi.org/10.3897/ zse.93.10995

Salvador RB, Charles L, Simone LRL, Maestrati P(2018) Terrestrial gastropods from Pedra Talhada Biological Reserve, Alagoas state, Brazil, with description of a new species of Radiodiscus (Gastropoda: Charopidae). Archiv für Molluskenkunde 147 (1): 101-128. https://doi.org/10.1127/arch.moll/147/101-128

Sandoval AC (1997) Caracoles terrestres (Mollusca: Gastropoda) de Iturbide, Nuevo León, México. Revista de Biología Tropical 44 45: 137-142.

Santos SB, Rodrigues CL, Nunes GKM, Miyahira IC, Viana TA, Oliveira JL, Fonseca FC, Silva PSC (2010) Estado do conhecimento da fauna de invertebrados não marinhos da Ilha Grande (Angra dos Reis, RJ). Oecologia Australis 14 (2): 504-549.

Silva FS, Simone LR, Salvador R (2019) Taxonomic study on a collection of terrestrial mollusks from the region of Santa Maria, Rio Grande do Sul state, Brazil. Arquivos De Zoologia, 50 (3): 175-190. https://doi.org/10.11606/2176-7793/2019.50.03

Schade FH (1965) Lista de los moluscos del Guaira (Villarrica - Paraguay) conocidos hasta el presente. Comunicaciones de la Sociedad Malacologica del Uruguay 1(8): 209-221.

Secutti S, Bichuette ME (2013) Ictiofauna da área cárstica de Presidente Olegário, Estado de Minas Gerais, com ênfase nas espécies subterrâneas. Revista da Biologia 10(2): 13-20.
Simone LRL (2006) Land and freshwater mollusks of Brazil. EGB/FAPESP, São Paulo.

Simone LRL (2012a) A new genus and species of cavernicolous Pomatiopsidae (Mollusca, Caenogastropoda) in Bahia, Brazil. Papéis Avulsos de Zoologia 52 (40): 515-524. https://doi.org/10.1590/S0031-10492012022000001

Simone LRL (2013) Habeas, a new genus of Diplommatinidae from Central Bahia, Brazil (Caenogastropoda), with description of three new species. Journal of Conchology 41 (4): 519-525.

Simone LRL (2015) Three new species of Kora (Pulmonata, Orthalicidae) from Bahia and Minas Gerais, Brazil. Journal of Conchology 42(1): 51-56.

Simone LRL, Moracchioli N (1994) Hydrobiidae (Gastropoda: Hydroboidea) from the Ribeira Valley. S.E. Brazil, with descriptions of two new cavernicolous species. Journal of Molluscan Studies 60: 445-459.

Simone LRL, Salvador RB (2016) Taxonomical study on a sample of land snails from Nanuque (Minas Gerais, Brazil), with descriptions of three new species. Stuttgarter Beiträge zur Naturkunde A, Neue Serie 9: 9-30. https://doi.org/10.18476/sbna. v9.a2

Simone LRL, Cavallari DC, Salvador RB (2020). A new troglobite species of Habeastrum Simone, 2019 from Brazil, and support for classification in Diplommatinidae (Mollusca, Caenogastropoda). Zoosystematics and Evolution 96 (2): 639-647.

Suter H (1900) Observações sobre alguns caracóis terrestres do Brasil. Revista do Museu Paulista 4: 329-337.

Trajano E (2000) Cave faunas in the Atlantic tropical rain forest: composition, ecology, and conservation. Biotropica 32 (4b): 882-893.

Trajano E, Bichuette ME (2010) Diversity of Brazilian subterranean invertebrates, with a list of troglomorphic taxa. Subterranean Biology 7: 1-16.

Wagner A.J (1907-1911) Die Familie Helicinidae. In: Mart ini FH, Chemnitz JW (Eds.). Systematische Conchilien Cabinet [1837-1920], Nuremberg (Bauer \& Raspe), 1-391.

Weigand AM (2013) New Zospeum species (Gastropoda, Ellobioidea, Carychiidae) from $980 \mathrm{~m}$ depth in the Lukina jama-Trojama cave system (Velebit Mts., Croatia). Subterranean Biology 11: 45-53.

Wurtz CB (1950) Resultados da Expedição das Índias Ocidentais Catherwood-Chaplin, 1948. Parte IV. Caracóis terrestres de North Cat Cay (Bahamas), Cayo Largo (Cuba), Grand Cayman, Saint Andrews e Old Providence. Anais da Academia de Ciências Naturais da Filadélfia, 102: 95-110.

Zepon T, Bichuette ME (2017) Influence of substrate on the richness and composition of Neotropical cave fauna. Supplementary Material. Anais da Academia Brasileira de Ciências: 1V14. https://doi.org/10.1590/00013765201720160452
Received: 01/12/2020

Revised: 13/02/2021

Accepted: 03/03/2021

Published online: 14/04/2021 